Available online at: http://ejournal.unpas.ac.id/index.php/litigasi

Litigasi, Vol. 17(2), 2016, 3517-3552

DOI: http://dx.doi.org/10.23969/litigasi.v17i2.156

\title{
EKSISTENSI PERLINDUNGAN SAKSI DAN KORBAN DALAM PERSPEKTIF SISTEM PERADILAN PIDANA DI INDONESIA
}

\section{TEDIE SUBARSYAH SUMADIKARA}

Fakultas Hukum Universitas Pasundan (UNPAS) Bandung, Jl. Lengkong Besar No. 68, Bandung 40261, Telp.022-4262226, Email: tedie.sby@unpas.ac.id.

\begin{abstract}
ABSTRAK
Sejalan dengan perkembangan tindak pidana saat ini, maka perlu pengembangan sistem peradilan pidana (SPP) dengan melibatkan komponen penting lain dalam sistem peradilan pidana, yaitu komponen i dcis $i$,ang melaksanakan fungsi perlindungan terhadap saksi dan/atau korban tindak pidana. pidana

Dengan melibatkan fungsi perlindungan dimaksud, maka sistem peradilan pidana tidak lagi hanya berorientasi kepada tersangka / terdakwa melainkan juga berorientasi kepada saksi dan korban tindak pidana. Hal ini akan berimplikasi pada pengembangan dan penguatan sistem peradilan pidana menjadi sistem peradilan pidana yang sempurna, yakni sistem peradilan pidana yang baik, seimbang dan adil. Sehingga di masa yang akan datang tidak terjadi lagi fenomena saksi dan / atau korban yang mengalami ancaman, tekanan atau terjadi rekayasa alat bukti keterangan saksi, bahkan pengabaian terhadap hak- hak saksi dan / atau korban.

Meskipun kini kehadiran LPSK telah memberikan jaminan dan kepastian bagi perlindungan saksi dan/atau korban tindak pidana, namun kedudukan LPSK sebagai komponen sistem peradilan pidana belum tegas diakui dalam hukum acara pidana. Oleh karena itu sangat penting untuk menganalisis kedudukan LPSK dalam sistem peradilan pidana di Indonesia, yaitu dengan mengkaji peran LPSK dalam sistem peradilan pidana, dan konsep kedudukan LPSK sebagai lembaga negara dalam sistem peradilan pidana di Indonesia.
\end{abstract}

Kata Kunci: Eksistensi Lembaga Perlindungan Saksi dan Korban.

Copyright (C) 2016, LITIGASI, p-ISSN: 0853-7100; e-ISSN: 2442-2274 
Available online at: http://ejournal.unpas.ac.id/index.php/litigasi

Litigasi, Vol. 17(2), 2016, 3517-3552

DOI: http://dx.doi.org/10.23969/litigasi.v17i2.156

\begin{abstract}
In line with the current development of the criminal offense, it is necessary to the development of the criminal justice system (SPP) with the involvement of other key components of the criminal justice system, component that carry out the functions of protection of witnesses and / or victims of crime. By involving the intended protection function, the criminal justice system is no longer just oriented to the suspect / defendant but also oriented to witnesses and victims of crime. This will have implications for the development and strengthening of the criminal justice system into the criminal justice system is perfect, the criminal justice system a good, balanced and fair. So that in the future does not happen again the phenomenon of witnesses and / or victims with threats, pressure or occur engineering evidence statements of witnesses, even a waiver of the rights of witnesses and / or victims.

Although now the presence of the Agency has given guarantees and assurances for the protection of witnesses and / or victims of crime, but the position of the Agency as a component of the criminal justice system has not been expressly recognized in the law of criminal procedure. Therefore it is very important to analyze the position of the Agency in the criminal justice system in Indonesia, namely by reviewing the Agency's role in the criminal justice system, and the concept of the position of the Agency as the state agencies in the criminal justice system in Indonesia.
\end{abstract}

Keywords: Existence of the Witness and Victim Protection Agency.

Copyright (C) 2016, LITIGASI, p-ISSN: 0853-7100; e-ISSN: 2442-2274 
Available online at: http://ejournal.unpas.ac.id/index.php/litigasi

Litigasi, Vol. 17(2), 2016, 3517-3552

DOI: http://dx.doi.org/10.23969/litigasi.v17i2.156

\section{PENDAHULUAN}

Keberadaan lembaga-lembaga baru termasuk Lembaga Perlindungan

Saksi dan Korban, secara umum diharapkan menjadi faktor pendorong dalam rangka check and balances, terwujudnya sistem administrasi negara yang baik, serta birokrasi pemerintahan yang berkualitas (Taufiq Effendi, 2010 : 234).

Di dalam Undang-Undang No. 13 Tahun 2006 dan Undang-Undang No. 31 Tahun 2014 Tentang Perubahan Atas UU No. 13 Tahun 2006 Tentang Perlindungan Saksi dan Korban maupun dalam Kitab Undang-Undang Hukum Acara Pidana (untuk selanjutnya disingkat KUHAP), tidak pernah disebutkan secara tersurat atau eksplisit bahwa lembaga yang melaksanakan fungsi perlindungan bagi saksi dan korban tindak pidana ini, yaitu Lembaga Perlindungan Saksi dan Korban (untuk selanjutnya disingkat LPSK) sebagai komponen Sistem Peradilan Pidana (untuk selanjutnya disingkat SPP). Kedudukan yang tidak jelas bagi LPSK, dalam praktik dapat berdampak pada koordinasi yang lemah antara LPSK dengan komponen-komponen dalam sistem peradilan pidana.

LPSK seolah-olah tidak mempunyai kedudukan yang sejajar dengan komponen-komponen dimaksud, sehingga tidak mempunyai posisi tawar yang kuat. Misalnya dalam beberapa koordinasi yang dilakukan ketika LPSK melakukan tindakan / langkah-langkah dalam kewenangan perlindungan dimaksud, seringkali harus menerima sikap-sikap yang tidak koordinatif bahkan cenderung resistant terhadap LPSK.

Copyright @ C 2016, LITIGASI, p-ISSN: 0853-7100; e-ISSN: 2442-2274 
Available online at: http://ejournal.unpas.ac.id/index.php/litigasi

Litigasi, Vol. 17(2), 2016, 3517-3552

DOI: http://dx.doi.org/10.23969/litigasi.v17i2.156

Dalam upaya meningkatkan kualitas penegakan hukum, maka sumber daya manusia aparat penegak hukum mutlak perlu ditingkatkan, sehingga tidak hanya mampu menerapkan norma-norma atau asas-asas yang terdapat di dalam hukum acara pidana, melainkan juga mampu mengikuti dan memahami kecenderungankecenderungan masyarakat yang terus berkembang. Dengan demikian yang terjadi bukan hanya penegakan hukum, melainkan juga penegakan keadilan.

Meskipun ada yang berpendapat bahwa dalam rangka penegakan hukum, keadilan tidak dapat dijadikan tujuan. Walaupun sesungguhnya diakui titik tolak penegakan hukum harus dilandasi oleh tujuan untuk mencapai kebenaran dan keadilan. Keadilan hanyalah merupakan cita-cita belaka dalam penegakan hukum yang senantiasa harus dihayati oleh setiap aparat penegak hukum, meskipun dalam kenyataannya tak dapat diketahui dengan pasti apakah cita-cita tersebut dapat tercapai atau tidak. Lebih lanjut dikemukakan bahwa kebenaran merupakan tujuan nyata dari penegakan hukum. Oleh sebab itu, kebenaranlah yang harus dicapai dalam usaha penegakan hukum (Satjipto Rahardjo, 2009: xiii).

Dalam proses penegakan hukum perkara pidana yang berupaya maksimal untuk menemukan "kebenaran materiil", sering muncul keluhan dari kalangan masyarakat tentang ketidakadilan dari pihak-pihak yang berkepentingan dalam perkara tersebut. Hal ini wajar karena proses penegakan hukum dalam perkara pidana merupakan proses interaksi nalar hukum dan nalar batin untuk mencapai puncak kearifan dan keadilan dalam mengungkap suatu perkara pidana tersebut (Artidjo Alkostar, 2007: 7).

Copyright @ C 2016, LITIGASI, p-ISSN: 0853-7100; e-ISSN: 2442-2274 
Available online at: http://ejournal.unpas.ac.id/index.php/litigasi

Litigasi, Vol. 17(2), 2016, 3517-3552

DOI: http://dx.doi.org/10.23969/litigasi.v17i2.156

Oleh karena itu terhadap putusan-putusan pengadilan dalam perkara pidana harus didasarkan atas bukti-bukti yang sah dan valid yang terungkap dan ditemukan dalam persidangan. Bukti-bukti yang diajukan oleh jaksa penuntut umum haruslah bukti-bukti yang autentik, valid dan meyakinkan sehingga dapat membangun adanya fakta-fakta hukum yang sah.

Situasi tersebut akan terkait dengan pentingnya salah satu alat bukti yaitu alat bukti keterangan saksi. Peranan saksi dan atau saksi korban dalam suatu tindak pidana adalah faktor penting untuk mengungkap suatu perkara pidana. Peranan tersebut dibutuhkan dalam pelaksanaan pemeriksaan baik pada tingkat penyidikan kepolisian, kejaksaan maupun saat proses pemeriksaan di persidangan. Kehadiran saksi dan korban yang objektif akan turut mendukung bahkan memperkuat alat bukti jaksa dalam mengungkap perkara tindak pidana.

Para penegak hukum dalam mencari dan menemukan kejelasan tentang tindak pidana yang dilakukan oleh pelaku tindak pidana sering mengalami kesulitan karena tidak dapat menghadirkan saksi dan/atau korban disebabkan adanya ancaman, baik fisik maupun psikis dari pihak tertentu (Konsideran Menimbang huruf "b", Undang-Undang Nomor 13 Tahun 2006).

Tidak dapat dipungkiri bahwa peranan saksi dan korban juga dapat menjadi alat bukti utama untuk memberikan petunjuk demi terungkapnya suatu perkara. Namun tidak sedikit saksi dan korban yang tidak mau dan tidak mampu memposisikan perannya untuk mengutarakan peristiwa yang terjadi, akibat banyaknya kendala dan persoalan seputar kemauan dan kemampuan diri dari saksi

Copyright $\odot$ 2016, LITIGASI, p-ISSN: 0853-7100; e-ISSN: 2442-2274 
dan korban tersebut. Menurut Soeharto, banyak dari saksi dan korban tindak pidana menolak menjadi saksi karena intimidasi dan ancaman dalam bentuk yang terburuk. Hal ini dapat mempengaruhi kemauan mereka untuk bersaksi, mereka dimungkinkan tidak ingin menjadi saksi karena takut adanya tindakan balasan (Soeharto, 2007: 144).

Terkait dengan LPSK, lembaga-lembaga baru tersebut, termasuk LPSK, disebut sebagai "auxiliary State's bodies/state auxiliary organs/youx diary institutions" yang diterjemahkan dengan "organ negara tambahan" atau sering juga disebut dengan istilah "lembaga negara bantu", "lembaga negara sampiran", "lembaga negara penunjang" (Jimly Asshiddiqie, Tanpa Tahun: 8) atau "lembaga non struktural". Merujuk pada batasan yang diberikan oleh Lembaga Adminstrasi Negara, lembaga non struktural adalah institusi yang dibentuk karena urgensi terhadap tugas khusus tertentu yang tidak dapat diwadahi dalam kelembagaan pemerintah (konvensional) dengan keunikan tertentu dan memiliki karakteristik tugas yang urgen, unik dan terintegrasi serta efektif (Hamdan Zoelva, 2010: 8).

LPSK sebagai lembaga yang lahir dalam era reformasi pasca amandemen UUD 1945 tersebut, berdasarkan Undang-Undang Perlindungan Saksi dan Korban (untuk selanjutnya Undang-Udang disingkat UU) disebutkan sebagai lembaga mandiri (Pasal 11 - 12, UU No. 13 Tahun 2006) yang memiliki tugas untuk melaksanakan fungsi yang spesifik yakni memberikan perlindungan terhadap saksi dan korban tindak pidana. Melihat pada karakteristik fungsi dan kewenangannya tersebut LPSK merupakan lembaga yang berada dalam lingkup sistem peradilan 
Available online at: http://ejournal.unpas.ac.id/index.php/litigasi

Litigasi, Vol. 17(2), 2016, 3517-3552

DOI: http://dx.doi.org/10.23969/litigasi.v17i2.156

pidana (Pasal 11 dan 12 A UU No. 31 Tahun 2014). Dalam hal ini terdapat tiga besaran bidang tugas substantif yang dimiliki LPSK, yang unik dan tidak dimiliki/dimandatkan kepada lembaga lainnya, yakni memberikan perlindungan bagi saksi tindak pidana, memberikan layanan bantuan medis dan rehabilitasi psikososial serta memfasilitasi permohonan kompensasi dan restitusi bagi korban tindak pidana.

Dengan fungsi khusus yang tidak menjadi fungsi lembaga-lembaga negara lainnya tersebut, LPSK harus menjadi lembaga yang kuat agar dalam menjalankan fungsi dan kewenangannya dapat sinergis dengan fungsi maupun kewenangan lembaga penegak hukum yang berada dalam sistem peradilan pidana. Terkait dengan penguatan tersebut, Presiden Susilo Bambang Yuhoyono pada waktu itu dalam Pidato Kenegaraan tanggal 16 Agustus 2011 menekankan perlunya penguatan beberapa lembaga yang berperan dalam pemberantasan korupsi yakni KPK, Pengadilan Tipikor, PPATK, dan LPSK agar dapat bekerja efektif untuk menjalankan tugas dan fungsinya. Dalam kerangka isu penguatan LPSK tersebut, perbaikan dan penguatan pada aspek kelembagaan LPSK adalah salah satu bagian penting dan mutlak sebagai realitas kebutuhan yang berkorelasi langsung dengan upaya peningkatan performa LPSK agar dapat bekerja efektif dan lebih optimal (Abdul Haris Semendawai, Materi Rapat Internal, 2012).

LPSK adalah lembaga yang dibentuk berdasarkan amanat Undang-Undang Nomor 13 tThun 2006 tentang Perlindungan Saksi dan Korban, yang telah disempurnakan dengan UU No. 31 Tahun 2014 Tentang Perubahan Atas UndangUndang Nomor 13 tahun 2006 tentang Perlindungan Saksi dan Korban. Secara

Copyright $\odot$ 2016, LITIGASI, p-ISSN: 0853-7100; e-ISSN: 2442-2274 
Available online at: http://ejournal.unpas.ac.id/index.php/litigasi

Litigasi, Vol. 17(2), 2016, 3517-3552

DOI: http://dx.doi.org/10.23969/litigasi.v17i2.156

khusus kehadiran LPSK sebagai lembaga yang lahir pasca reformasi ini, dimaksudkan untuk menjadi semangat dalam menumbuh-kembangkan partisipasi masyarakat dalam mengungkap tindak pidana, dengan cara memberikan perlindungan bagi setiap orang yang menjadi saksi dan/atau korban. Hal ini disebabkan selama ini keberadaan Saksi dan Korban dalam proses peradilan pidana kurang mendapat perhatian, meskipun perannya sangat penting dalam pengungkapan tidak pidana.

Untuk mewujudkan partisipasi masyarakat dimaksud diperlukan sebuah lembaga yang mandiri atau independen (Pasal 11 UU No. 13 Tahun 2006), yang khusus melaksanakan fungsi perlindungan terhadap saksi dan korban tindak pidana. Oleh karena itu, dalam hal ini lahirnya LPSK sekaligus pula melengkapi sistem peradilan pidana agar tidak hanya berorientasi kepada pelaku tindak pidana, melainkan secara seimbang memberikan perhatian terhadap pentingnya aspek perlindungan bagi saksi dan/atau korban tindak pidana.

LPSK sebagai lembaga negara yang tergolong baru, yang memiliki tanggungjawab melaksanakan fungsi perlindungan sebagaimana maksud di atas, tidak Iuput dari kendala, baik yang bersifat administratif-fasilitatif maupun substantif. Kendala yang sekaligus menjadi keterbatasan LPSK tersebut utamanya disebabkan oleh beberapa kelemahan yang terdapat di dalam UU No. 13 Tahun 2006 Tentang Perlindungan Saksi dan Korban, yang antara lain misalnya terkait dengan kelembagaan, khususnya kedudukan LPSK dalam sistem peradilan pidana. Kendati demikian, permohonan masyarakat untuk mendapatkan perlindungan saksi dan korban, sejak awal berdirinya LPSK tidak pernah surut, bahkan selalu mengalami

Copyright @ C 2016, LITIGASI, p-ISSN: 0853-7100; e-ISSN: 2442-2274 
peningkatan dalam setiap tahunnya. Diperoleh data bahwa: (Unit Penerimaaan Permohonan (UPP) - LPSK, 2014) pada tahun 2008/2009 terdapat 84 permohonan; tahun 2010 sebanyak 154 permohonan; tahun 2011 sebanyak 340 permohonan; tahun 2012 sebanyak 655 permohonan; dan tahun 2013 terdapat 1.554 permohonan.

Meningkatnya kuantitas permohonan tersebut menunjukkan, bahwa semakin besar harapan masyarakat terhadap LPSK. Hal ini menunjukkan pula semakin diakui dan diterimanya peran penting dan keberadaan LPSK dalam proses peradilan pidana atau penegakan hukum. Di sisi lain, meningkatnya permohonan sebagaimana dikemukakan di atas, menuntut penguatan kemampuan dan kewenangan serta penguatan peran penting LPSK sebagai lembaga yang diamanatkan undang-undang untuk melaksanakan perlindungan saksi dan korban. Akan tetapi kedudukan LPSK dalam sistem peradilan pidana berdasarkan UU No. 13 Tahun 2013 Tentang Perlindungan Saksi dan Korban maupun UU No. 31 Tahun 2014, tidak dalam posisi yang jelas, apakah LPSK merupakan komponen atau bagian dari sistem peradilan pidana atau LPSK berada di luar sistem peradilan pidana. Adapun dalam naskah ini yang menjadi fokus pembahasan yaitu:

1. Apakah yang menjadi peran Lembaga Perlindungan Saksi dan Korban terkait dengan sistem peradilan pidana?

2. Apakah LPSK merupakan sebuah lembaga Negara dalam konteks sistem peradilan pidana di Indonesia?

Copyright (C) 2016, LITIGASI, p-ISSN: 0853-7100; e-ISSN: 2442-2274 
Available online at: http://ejournal.unpas.ac.id/index.php/litigasi

Litigasi, Vol. 17(2), 2016, 3517-3552

DOI: http://dx.doi.org/10.23969/litigasi.v17i2.156

\section{PEMBAHASAN}

Kita sepakat bahwa, pada dasarnya setelah merdeka, Indonesia adalah negara yang berdasar hukum, negara memandang komitmen bahwa setiap orang harus diperlakukan secara baik dan adil, apakah ia seorang tersangka atau korban tindak pidana. Perikemanusiaan sebagai salah satu sendi nilai falsafah negara Pancasila menjiwai seluruh keberadaan hukum di negara kita, mulai dari UUD 1945 hingga kepada seluruh peraturan perundang-undangan (Arif Gosita, 1986 : 14). Hal inilah yang harus dipadukan dengan asas-asas yang terbaik bagi perlakuan terhadap warga dari suatu negara yang telah merdeka dan didirikan sebagai negara hukum menurut undang-undang dasarnya, sehingga terdapat keserasian antara pelaksanaan tugas oleh aparat penegak hukum dan hak-hak asasi yang melekat pada seorang yang kebetulan terlibat dalam perkara pidana (Hanafi Asmawie, 1989: 79).

Posisi saksi dan korban dalam suatu tindak pidana mengandung masalah hukum yang tidak selalu mudah dipecahkan dari sudut hukum, oleh karenanya seorang saksi atau korban tindak pidana dapat dimungkinkan akan mengalami korban berikutnya, yang disebut dengan secondary victimization, disebabkan adanya penolakan secara sistematis oleh sistem peradilan pidana (Hanafi Asmawie, 1989: 79).

Hukum memiliki andil dalam konstruksi proses viktimisasi dengan orientasi hukum pidana yang sangat terbatas dan tradisional, persoalan korban (termasuk di dalamnya saksi) menjadi persoalan sepele dan tidak diperhatikan (Mien Rukmini, 2006: 4). Dalam rangka konsep pengaturan terhadap korban atau saksi kejahatan,

Copyright @ 2016 , LITIGASI, p-ISSN: 0853-7100; e-ISSN: 2442-2274 
pertama-tama yang diperhatikan adalah esensi kerugian yang diderita saksi dan korban. Ternyata esensi kerugian tersebut tidak hanya bersifat materiil atau penderitaan fisik saja melainkan juga yang bersifat psikologis (Muladi dan Barda Nawawi Arief, 2007: 84). Situasi inilah yang selanjutnya dapat memicu terjadinya trauma dari para saksi dan korban tindak pidana untuk memposisikan diri untuk tidak mendukung proses peradilan selanjutnya atau mengundurkan diri dari posisinya sebagai saksi.

Dalam Pasal 27 ayat (1) UUD 1945 disebutkan bahwa :

"Segala warga negara bersamaan kedudukannya di dalam hukum dan pemerintahan dan wajib menjunjung hukum dan pemerintahan itu dengan tidak ada kecualinya".

Ayat ini mengisyaratkan suatu asas hukum yang sangat fundamental yaitu asas persamaan kedudukan dalam hukum atau dikenal dengan istilah "Equolity Before the Law" (Mien Rukmini, 2003: 63). Dengan demikian menurut konstitusi kita, tidak terdapat perbedaan di depan hukum dan pemerintahan terhadap adanya golongan dalam masyarakat baik adanya golongan yang didasarkan atas geografis, ras, suku maupun antara status profesi.

Hal tersebut di atas juga dikatakan oleh Mien Rukmini bahwa: (Mien Rukmini, 2003: 104) pemahaman kita akan istilah "sama" disini adalah wajib dihindarinya diskriminasi berdasarkan : "race, colour, sex, language, religion, politicat or other opinion, nation or sociol organ, property, birth or other status.

Pada dasarnya asas persamaan kedudukan dalam hukum harus dapat

Copyright @ C 2016, LITIGASI, p-ISSN: 0853-7100; e-ISSN: 2442-2274 
Available online at: http://ejournal.unpas.ac.id/index.php/litigasi

Litigasi, Vol. 17(2), 2016, 3517-3552

DOI: http://dx.doi.org/10.23969/litigasi.v17i2.156

diimplementasikan dalam peraturan-peraturan, demi tegaknya hukum dan keadilan. Tanpa diterapkannya asas ini mustahil peradilan yang adil dan benar dapat diwujudkan (Mien Rukmini, 2003: 85).

Setiap warga negara yang baik ialah warga negara yang mengetahui hak dan kewajibannya. Salah satu hak dan kewajiban yang dibebankan hukum kepada setiap warga negara, mereka harus ikut membela kepentingan umum. Salah satu aspek dari pembelaan kepentingan umum, adalah ikut ambil bagian dalam penyelesaian tindak pidana, apabila dalam penyelesaian itu diperlukan keterangannya (M. Yahya Harahap, 1988: 680). Disamping sebagai pelaku, individu sebagai anggota masyarakat juga sebagai korban dan saksi dari suatu peristiwa yang terjadi, karena saat kejadian dia melihat, mendengar dan menyaksikannya secara langsung.

Dalam hal ini baik korban atau saksi tersebut punya kewajiban moral untuk memberitahukan, melaporkan atau mengadukan peristiwa yang terjadi atau yang dialaminya pada kepolisian sebagai langkah awal proses peradilan pidana. Sebagai kelanjutannya baik saksi maupun korban juga berkewajiban untuk berperan langsung sebagai saksi terhadap perkara dimaksud sampai perkaranya dinyatakan selesai oleh pengadilan melalui putusannya.

Agar saksi dan korban tersebut bersedia menjadi saksi dan tidak merasa khawatir akan adanya ancaman dari pihak-pihak tertentu, maka harus dipikirkan untuk memberikan adanya suatu upaya perlindungan. Menurut Soeharto, bahwa untuk itu langkah-langkah perlindungan dapat diminta baik oleh saksi atau korban bagi yang benar-benar takut. Sidang pengadilan harus menentukan letak

Copyright @ 2016 , LITIGASI, p-ISSN: 0853-7100; e-ISSN: 2442-2274 
Available online at: http://ejournal.unpas.ac.id/index.php/litigasi

Litigasi, Vol. 17(2), 2016, 3517-3552

DOI: http://dx.doi.org/10.23969/litigasi.v17i2.156

keseimbangan antara hak dari terdakwa dan hak adanya perlindungan kepada saksi (Soeharto, 2007: 144).

Dikdik M. Arief Mansur \& Elisatris Gultom juga berpandapat bahwa pada saat saksi (korban) akan memberikan keterangan, tentunya harus disertai jaminan bahwa yang bersangkutan terbebas dari rasa takut sebelum, pada saat dan setelah memberikan kesaksian. Jaminan ini penting untuk diberikan guna memastikan bahwa keterangan yang akan diberikan benar-benar murni dan bukan rekayasa karena adanya tekanan (Dikdik M. Arief Mansur dan Elisatris Gultom, 2007: 152).

Lebih lanjut dalam Penjelasan Undang-Undang Nomor 13 tahun 2006 tentang perlindungan saksi dan korban dinyatakan pula bahwa "sudah saatnya perlindungan terhadap saksi dan korban diatur dengan undang-undang tersendiri. Berdasarkan asas kesamaan kedudukan di depan hukum yang menjadi salah satu ciri negara hukum, seorang saksi dan korban dalam proses peradilan pidana harus diberikan jaminan perlindungan, tidak hanya melihat hak-hak tersangka/terdakwa pelaku kejahatan saja" (Penjelasan Umum atas UU No. 13 Tahun 2006).

Proses perlindungannya diberikan sejak tahap penyelidikan dimulai, dan berakhir sesuai dengan ketentuan sebagaimana diatur dalam Undang-Undang Nomor 13 tahun 2006 tentang perlindungan saksi dan korban. Berkenaan dengan hal tersebut, dengan berlakunya Undang-Undang Nomor 13 tahun 2006 tentang perlindungan saksi dan korban, diharapkan dalam pemberian hak kepada seorang saksi dan korban dapat berjalan sebagaimana mestinya.

Copyright @ 2016, LITIGASI, p-ISSN: 0853-7100; e-ISSN: 2442-2274 
Available online at: http://ejournal.unpas.ac.id/index.php/litigasi

Litigasi, Vol. 17(2), 2016, 3517-3552

DOI: http://dx.doi.org/10.23969/litigasi.v17i2.156

Undang-Undang Nomor 13 tahun 2006 tentang perlindungan saksi dan korban dimaksudkan agar setiap orang yang menjadi saksi dan korban tindak pidana dalam suatu perkara pidana, akan merasa nyaman saat ia memberikan keterangan guna kepentingan penegakan hukum. Posisi penting dari keberadaan saksi dan korban tindak pidana dalam sebuah proses penegakan hukum, akan menjadi masukan untuk menentukan bentuk-bentuk dan teknis perlindungan yang lebih efektif agar dalam setiap proses penegakan hukum selalu dapat dihadiri oleh saksi dan korban yang selama ini mempunyai posisi yang sangat penting dalam setiap upaya untuk mengungkap sebuah kebenaran dari fakta hukum, khususnya dalam suatu persidangan. Tentunya lebih jauh dan lebih khusus akan membantu bagi penyidik kepolisian, kejaksaan dan secara khusus terhadap para Hakim dalam membuat pertimbangan hukum dan menentukan amar putusannya sesuai dengan pengungkapan perkara secara lebih optimal untuk mencapai harapan terhadap rasa keadilan.

Menyikapi persoalan tersebut, Indonesia kemudian membentuk Lembaga Perlindungan Saksi Dan Korban (selanjutnya disingkat LPSK) yang telah diamanatkan oleh Undang-Undang Nomor 13 tahun 2006 Tentang Perlindungan Saksi dan Korban (selanjutnya disingkat UU PSK). Diundangkannya undang-undang ini adalah sebagai upaya serius bagi Indonesia dalam menghargai pentingnya kedudukan dan peranan saksi dan korban dalam pengungkapan perkara pidana pada proses penegakan hukum.

Copyright @ 2016 , LITIGASI, p-ISSN: 0853-7100; e-ISSN: 2442-2274 
Available online at: http://ejournal.unpas.ac.id/index.php/litigasi

Litigasi, Vol. 17(2), 2016, 3517-3552

DOI: http://dx.doi.org/10.23969/litigasi.v17i2.156

Keberadaan LPSK, dalam sistem peradilan pidana ini sangat diharapkan dapat mengatasi kelemahan penegakan hukum di Indonesia, terutama ditandai dengan pentingnya hubungan antara sub-sistem dengan sub-sistem yang lain dalam sistem peradilan pidana, serta hubungannya dengan LPSK sebagai lembaga yang memberikan perlindungan terhadap keberadaan saksi dan korban.

Ditengah krisis multidimensi yang saat ini melanda Indonesia, salah satu aspek yang menjadi perhatian masyarakat untuk segera diperbaiki adalah di bidang penegakan hukum, tingkat kepercayaan warga masyarakat yang buruk terhadap penegakan hukum (law enforcement) telah menimbulkan dampak negatif, seperti peningkatan kriminalitas dan tindakan kekerasan lainnya (Achmad Ali, 2001: 100 101). Gambaran penegakan hukum di Indonesia tersebut juga terungkap dalam laporan Asion Intelligent Issue pada tahun 1997 menempatkan Indonesia sebagai negara yang tingkat korupsinya sangat tinggi. Demikian pula dalam laporan Political and Economic Risk Consultancy (PERC) yang menempatkan Indonesia diperingkat tertinggi bersama Cina dan India (Juanda, 2003: 1). Data tersebut setelah beberapa tahun belum mengalami perubahan yang signifikan dan hal ini tercermin dalam International Tranparency pada tahun 2006, yang menempatkan Indonesia pada urutan keenam negara paling korup di antara 133 negara.

Selain kondisi yang demikian itu, berdasarkan penelitian Badan Perencanaan Pembangunan Nasional (Bappenas), sistem hukum Indonesia berada dalam keadaan "gawat" (desperate but not hopeless). Temuan yang diperoleh studi tersebut menemukan adanya kelemahan-kelemahan dalam pembangunan hukum di Indonesia

Copyright @ C 2016, LITIGASI, p-ISSN: 0853-7100; e-ISSN: 2442-2274 
selama 30 tahun. Hal ini kemudian disusul dengan kejadian-kejadian setelah tahun 1998, yang secara fundamental sistem hukum (termasuk sistem peradilan) Indonesia dianggap lemah atau rapuh. Hal inilah yang mengakibatkan ketidakpercayaan masyarakat pada lembaga-lembaga hukum (Mardjono Reksodiputro, $2003: 12$ ).

Sebagaimana disebutkan oleh Soerjono Soekanto (1983: 30) bahwa ada empat faktor yang menetukan berfungsinya kaidah hukum yaitu; kaidah hukum atau peraturan itu sendiri, petugas yang menegakkan atau yang menetapkan, fasilitas yang diharapkan akan dapat mendukung pelaksanaan kaidah hukum, dan warga masyarakat yang terkena ruang lingkup peraturan tersebut. Dengan demikian hubungan timbal balik antara materi perundang-undangan, aparat penegak hukum dengan kesadaran hukum dan ketaatan masyarakat sangat erat. Ketiga elemen itu harus berfungsi dengan baik, sehingga citra dan wibawa hukum dapat terwujud (Sjahran Basah, 1986: 9-10).

Dalam pandangan lain, I Gde Pantja Astawa (2001: 66-67) menyebutkan bahwa yang penting dalam penegakan hukum adalah orang-orang yang diserahi tugas untuk menegakkan hukum yaitu aparat penegak hukum. Jika sistemnya baik tapi orang-orangnya busuk maka penegakan hukumnya tidak jalan. Tetapi sebaliknya seburuk apapun sistemnya, jika orang-orangnya bersih maka penegakan hukum masih bisa jalan. Sebagus apapun peraturannya tapi jika penegakannya berada di tangan orang-orang yang kotor, maka pasti tidak jalan. Namun sebaliknya, walaupun peraturannya biasa-biasa saja tapi jika dilakukan orang-orang yang jujur dan baik 
Available online at: http://ejournal.unpas.ac.id/index.php/litigasi

Litigasi, Vol. 17(2), 2016, 3517-3552

DOI: http://dx.doi.org/10.23969/litigasi.v17i2.156

moralnya, maka hukum akan bisa jalan.

Mardjono Reksodipoetro (1994) merumuskan pengertian sistem peradilan pidana sebagai sistem pengendalian kejahatan yang terdiri dari lembaga-lembaga kepolisian, kejaksaan, pengadilan dan pemasyarakatan terpidana. Selanjutnya dikemukakan pula tujuan sistem peradilan pidana adalah mencegah masyarakat menjadi korban kejahatan; menyelesaikan kasus kejahatan yang terjadi sehingga masyarakat puas bahwa keadilan telah ditegakkan dan yang bersalah dipidana; dan mengusahakan agar mereka yang pernah melakukan kejahatan tidak mengulangi lagi kejahatannya.

Beberapa sudut pendekatan dalam sistem peradilan pidana dimaksud yang sesungguhnya tidak dapat dipisahkan satu sama lain, yaitu sudut pendekatan normatif, pendekatan manajemen dan pendekatan sosial. Lebih jauh bahkan ketiga bentuk pendekatan tersebut saling mempengaruhi dalam menentukan keberhasilannya (Romli Atmasasmita, 2010).

Tiga bentuk pendekatan tersebut adalah pendekatan normatif yang memandang aparatur penegak hukum sebagai institusi pelaksana peraturan perundang-undangan yang berlaku, yang tidak bisa terpisahkan dari sistem penegakan hukum; dan pendekatan administratif memandang aparatur penegak hukum sebagai suatu organisasi manajemen yang memiliki mekanisme kerja, baik hubungan yang bersifat horisontal maupun yang bersifat vertikal sesuai dengan struktur organisasi yang berlaku dalam organisasi tersebut; sedangkan pendekatan sosial memandang aparatur penegak hukum merupakan bagian yang tidak

Copyright @ C 2016, LITIGASI, p-ISSN: 0853-7100; e-ISSN: 2442-2274 
Available online at: http://ejournal.unpas.ac.id/index.php/litigasi

Litigasi, Vol. 17(2), 2016, 3517-3552

DOI: http://dx.doi.org/10.23969/litigasi.v17i2.156

terpisahkan dari suatu sistem sosial sehingga masyarakat secara keseluruhan ikut bertanggung jawab atas keberhasilan atau ketidakberhasilan dari keempat aparatur penegak hukum tersebut dalam melaksanakan tugasnya.

Dalam pemahaman penegakan hukum pidana menurut Hebert Packer (1988: 152 - 153) diperlukan suatu pendekatan pragmatis. Terkait dengan itu perlu mengabstraksi kenyataan dan bangunan model untuk mengatasi perilaku antisosial. Model dimaksud adalah model yang memiliki kegunaan sebagai indeks dari pilihan nilai masa kini tentang bagaimana suatu sistem diimplementasikan; model yang terbentuk dari usaha untuk membedakan secara tajam hukum dalam buku teks dan menjelaskan seakurat mungkin apa yang sedang terjadi dalam kehidupan nyata dari proses hukum pidana; dan model yang dapat digunakan untuk mengenali secara eksplisit pilihan nilai eksplisit atau implisit yang melandasi rincian suatu proses penegakan hukum pidana. Dikatakan lebih lanjut bahwa untuk itu model yang diperlukan adalah model atau model-model normatif (normative models). Ditegaskan pula bahwa dua model yang merupakan antinomi normatif dari jiwa hukum pidana (at the heart ofthe crimlnal law) tersebut adalah the due process model dan the crime control model.

Herbert Packer (1988: 154 - 173) menguraikan mengenai nilai-nilai yang melandasi kedua model di atas, sebagaimana dijelaskan pula Romli Atamasasmita (2010: 16 - 24) tentang kesamaan dan perbedaan yang tampak dari nilai-nilai, sesuai dengan kondisi sosial, budaya dan struktural, yang dijadikan landasan kerja kedua model tersebut. Dalam hal ini karakter nilai-nilai yang melandasi crime control

Copyright @ 2016, LITIGASI, p-ISSN: 0853-7100; e-ISSN: 2442-2274 
Available online at: http://ejournal.unpas.ac.id/index.php/litigasi

Litigasi, Vol. 17(2), 2016, 3517-3552

DOI: http://dx.doi.org/10.23969/litigasi.v17i2.156

model adalah:

1. Tindakan represif terhadap suatu tindakan kriminal merupakan fungsi terpenting dari suatu proses peradilan;

2. Perhatian utama harus ditujukan untuk efisiensi dari suatu penegakan hukum untuk menyeleksi tersangka, menetapkan kesalahannya dan menjamin atau melindungi hak tersangka dalam proses peradilannya;

3. Proses kriminal penegakan hukum harus dilaksanakan berlandaskan prinsip cepat dan tuntas, dan model yang dapat mendukung proses penegakan hukum tersebut adalah harus model administratif dan menyerupai model manajerial;

4. Asas praduga bersalah akan menyebabkan sistem ini dilaksanakan secara efisien;

5. Proses penegakan hukum harus menitik-beratkan pada kualitas temuantemuan fakta administratif, karena temuan tersebut akan membawa ke arah pembebasan seorang tersangka dari penuntutan atau kesediaan tersangka menyatakan dirinya bersalah (plead of guilty).

Adapun karakter nilai-nilai yang melandasi due process model adalah:

1. Perhatian utama pada formal-adjudicative dan adversary fact- finding, artinya dalam setiap kasus tersangka harus diajukan ke muka pengadilan yang tidak memihak, dan diperiksa sesudah tersangka memperoleh hak yang penuh untuk mengajukan pembelaannya;

Copyright @ C 2016, LITIGASI, p-ISSN: 0853-7100; e-ISSN: 2442-2274 
Available online at: http://ejournal.unpas.ac.id/index.php/litigasi

Litigasi, Vol. 17(2), 2016, 3517-3552

DOI: http://dx.doi.org/10.23969/litigasi.v17i2.156

2. Lebih mengutamakan pencegahan (preventive measures) dan menghapuskan sejauh mungkin kesalahan mekanisme peradilan;

3. Proses peradilan harus dikendalikan karena kekuasaan cenderung disalahgunakan atau memiliki potensi untuk menempatkan individu pada posisi yang menekan (coercive) dari negara;

4. Model ini bertitik tolak dari nilai yang bersifat anti terhadap kekuasaan, sehingga memegang teguh pada doktrin legal guilt, yang memiliki konsep pemikiran bahwa seseorang dianggap bersalah apabila penetapan kesalahannya dilakukan secara prosedural dan dilakukan oleh mereka yang mempunyai kewenangan untuk tugas tersebut. Selain itu penetapan kesalahan seseorang hanya dapat dilakukan oleh pengadilan yang tidak memihak. Dalam konsep ini terkandung asas praduga tak bersalah.

5. Mengutamakan gagasan equality before the law, sehingga negara harus menyediakan fasilitas yang sama untuk setiap orang yang berurusan dengan hukum;

6. Mengutamakan kesusilaan dan kegunaan sanksi pidana.

Perbedaan lain dari kedua model di atas adalah terletak pada mekanisme atau tahapan dan tipologi yang dianut model dimaksud. Crime control model sebagai tipe affirmative model selalu menekankan pada eksistensi dan penggunaan kekuasaan formal pada setiap tahap proses peradilan, serta kekuasaan legislatif sangat dominan. Berbeda dari itu adalah due process model sebagai negative model yang selalu

Copyright @ C 2016, LITIGASI, p-ISSN: 0853-7100; e-ISSN: 2442-2274 
Available online at: http://ejournal.unpas.ac.id/index.php/litigasi

Litigasi, Vol. 17(2), 2016, 3517-3552

DOI: http://dx.doi.org/10.23969/litigasi.v17i2.156

menekankan pembatasan pada kekuasaan formal dan modifikasi dari penggunaan kekuasaan tersebut kekuasaan yang lebih dominan adalah kekuasaan yudikatif dan selalu mengacu pada konstitusi.

Berkaitan dengan itu Remington dan Ohlin (Romli Atmasasmita, 2010: 14) mengemukakan pendapatnya tentang Criminal Justice System yaitu, bahwa peradilan pidana sebagai suatu sistem merupakan hasil interaksi antara peraturan perundangundangan, praktik administrasi dan sikap atau tingkah laku sosial. Pengertian sistem itu sendiri implikasi suatu proses interaksi yang dipersiapkan secara rasional dan dengan cara efisien untuk memberikan hasil tertentu dengan segala keterbatasannya.

Makna sistem dalam sistem peradilan pidana adalah adanya sinkronisasi dalam mencapai tujuan dari peradilan pidana. Menurut Muladi (1997) sinkronisasi atau keserempakan dan keselarasan adalah meliputi sinkronisasi struktural, sinkronisasi substansial dan sinkronisasi kultural. Sinkronisasi struktural adalah keserempakan dan keselarasan dalam kerangka hubungan antar lembaga; sinkronisasi substansial yaitu keserempakan dan keselarasan yang bersifat vertikal dan horisontal dalam kaitannya dengan hukum positif; dan sinkronisasi kultural adalah keserempakan dan keselarasan dalam menghayati pandangan-pandangan, sikap-sikap dan falsafah yang secara menyeluruh mendasari jalannya sistem peradilan pidana. Dalam hal ini, menurut penulis keserempakan dan keselarasan itu termasuk juga dalam pandangan, sikap dan falsafahnya terhadap tujuan sistem peradilan pidana yakni mewujudkan ketertiban masyarakat dan kemanfaatan bagi pelaku dan saksi/korban. Dengan kata lain, sistem peradilan pidana harus mampu menghadirkan keadilan yang tidak

Copyright @ C 2016, LITIGASI, p-ISSN: 0853-7100; e-ISSN: 2442-2274 
memihak, berimbang, baik terhadap pelaku, saksi maupun korban. Penegakan hukum yang diwujudkan dalam sistem peradilan pidana, secara umum dikemukakan pula oleh Muladi (1997: 6-7) bahwa penegakan hukum yang dapat menjamin kepastian hukum, ketertiban dan perlindungan hukum pada zaman modern dan era globalisasi ini hanya dapat terlaksana, apabila pelbagai dimensi kehidupan hukum selalu menjaga keselarasan, keseimbangan dan keserasian antara moralitas sosial, moralitas kelembagaan dan moralitas sipil yang didasarkan oleh nilai-nilai aktual di dalam masyarakat beradab, baik nasional maupun internasional.

Dalam sistem peradilan pidana, proses peradilan yang dimulai dari penyelidikan, penyidikan hingga pemeriksaan di persidangan menjadi sentral dari sistem peradilan pidana, karena keberhasilan pengungkapan suatu tindak pidana, mengenai terbukti atau tidak terbuktinya perbuatan seseorang terletak dalam proses peradilan pidana. Oleh karena itu keberhasilan mengungkap dan membuktikan suatu tindak pidana dapat menjadi keberhasilan sekaligus menjadi parameter dan indikator keberhasilan sistem peradilan pidana. Terkait dengan itu, prinsip peradilan pidana yang baik, seimbang dan adil menjadi aspek yang sangat penting. Prinsip ini bahkan sejatinya menjadi prinsip yang sangat penting dan paling utama dalam upaya membangun hukum pidana formil. Dengan kata lain pada sistem peradilan, peradilan (pidana) yang baik, seimbang dan adil harus mampu menjadi titik pandang hukum (Satjipto Rahardjo, 2006).

Sebagai titik pandang, artinya mempunyai tempat dalam asas atau prinsip. Dengan demikian prinsip ini harus menjadi pondasi, mengawal dan senantiasa 
Available online at: http://ejournal.unpas.ac.id/index.php/litigasi

Litigasi, Vol. 17(2), 2016, 3517-3552

DOI: http://dx.doi.org/10.23969/litigasi.v17i2.156

berdaya hidup didalam proses sekaligus sistem peradilan pidana. Sebagai suatu prinsip atau asas, maka pada tataran implementasi kehadiran asas ini juga merupakan isyarat bahwa diperlukan hukum yang mengakomodasi asas dimaksud, sehingga dapat bermakna, berperan dan berfungsi dalam mengaktualisasikannya.

Sistem peradilan pidana yang baik, seimbang dan adil, hakikatnya adalah sistem peradilan yang seluruh fungsinya dapat berjalan dengan baik, termasuk fungsi perlindungan, di samping fungsi-fungsi lainnya. Artinya pada sistem peradilan pidana juga harus mampu menjaga keseimbangan antara hak-hak saksi, korban dan hak-hak tersangka/terdakwa. Dalam konteks hak saksi dan korban, harus merupakan suatu kepastian dalam hal memperoleh alat bukti berupa keterangan dari seorang saksi yang dijamin oleh hukum atas hak-haknya. Dengan demikian dari penerapan asas dimaksud, diharapkan keterangan dari seorang saksi merupakan keterangan yang sebenarnya, yang diberikan dalam situasi dan kondisi normal, tidak dalam ancaman, tekanan atau paksaan, atau dalam kondisi terpojok.

A. Peran Lembaga Perlindungan Saksi dan Korban Terkait dengan Sistem Peradilan Pidana

Secara garis besar pengakuan fungsi perlindungan sebagai bagian dari fungsi sistem peradilan pidana adalah sangat penting untuk menjadikan performa sistem peradilan pidana yang baik, seimbang dan adil. Dengan berjalannya fungsi perlindungan pada sistem peradilan pidana yang baik, seimbang dan adil dimaksud, maka terdapat kepastian dan keseimbangan antara

Copyright @ 2016 , LITIGASI, p-ISSN: 0853-7100; e-ISSN: 2442-2274 
Available online at: http://ejournal.unpas.ac.id/index.php/litigasi

Litigasi, Vol. 17(2), 2016, 3517-3552

DOI: http://dx.doi.org/10.23969/litigasi.v17i2.156

hak-hak saksi, korban maupun hak-hak tersangka/terdakwa. Artinya dalam berjalannya sistem dimaksud bagi setiap saksi dan/atau korban terdapat kepastian yang dijamin oleh hukum dalam hal mendapatkan hak-haknya ketika tampil memberikan keterangan sebagai alat bukti dalam proses peradilan pidana. Hak-hak yang akan diperoleh bagi saksi dan/atau korban dalam peradilan pidana yang baik, seimbang dan adil, adalah hak-hak yang terkait dengan aspek keselamatan, keamanan dan kenyamanan, terkait adanya informasi atau keterangan yang diberikannya. Saksi dan/atau korban dalam kondisi terancam secara fisik maupun psikhis, tidak dapat dimintakan keterangan sebagai saksi dalam setiap proses peradilan, bahkan keterangan yang diberikan dalam kondisi terganggu kenyamanan dan keselamatannya, seharusnya dapat dibatalkan. Dengan demikian implementasi fungsi perlindungan dimaksud akan memberikan hak perlindungan bagi saksi dan/atau korban. Hal ini akan menjamin kepastian keterangan dari seorang saksi sebagai keterangan yang diberikan dalam situasi dan kondisi yang normal, tidak terdapat ancaman atau paksaan, tidak dalam tekanan atau kondisi terpojok.

Mencermati pelaksanaan perlindungan, UU Perlindungan Saksi dan Korban telah mengatur mengenai tata cara pemberian perlindungan sebagaimana telah diuraikan dalam bab sebelumnya. Tata cara tersebut pada intinya mengatur dan menentukan bagaimana seorang saksi dan/atau korban tindak pidana dapat memperoleh perlindungan atas hak-haknya, baik yang disebutkan di dalam Pasal 5, Pasal 6 maupun Pasal 7 UU No. 13 Tahun 2006

Copyright @ 2016 , LITIGASI, p-ISSN: 0853-7100; e-ISSN: 2442-2274 
Available online at: http://ejournal.unpas.ac.id/index.php/litigasi

Litigasi, Vol. 17(2), 2016, 3517-3552

DOI: http://dx.doi.org/10.23969/litigasi.v17i2.156

Tentang Perlindungan Saksi dan Korban, sebagaimana pasal-pasal dimaksud kini telah disempurnakan di dalam UU No. 31 Tahun 2014 Tentang Perubahan atas UU No. 13 Tahun 2006 Tentang Perlindungan Saksi dan Korban.

Hak yang disebutkan di dalam Pasal 5 ayat (1) UU Perlindungan Saksi dan Korban dimaksud, yaitu hak:

a. Memperoleh perlindungan atas keamanan pribadi, keluarga, dan harta bendanya, serta bebas dari ancaman yang berkenaan dengan kesaksian yang akan, sedang, atau telah diberikannya;

b. Ikut serta dalam proses memilih dan menentukan bentuk perlindungan dan dukungan keamanan;

c. Memberikan keterangan tanpa tekanan;

d. Mendapat penerjemah;

e. Bebas dari pertanyaan yang menjerat;

f. Mendapatkan informasi mengenai perkembangan kasus;

g. Mendapatkan informasi mengenai putusan pengadilan;

h. Mendapatkan informasi dalam hal terpidana dibebaskan;

i. Dirahasiakan identitasnya;

j. Mendapatkan identitas baru;

k. Mendapatkan tempat kediaman sementara;

I. Mendapatkan tempat kediaman baru;

m. Memperoleh penggantian biaya transportasi sesuai dengan kebutuhan;

n. Mendapat nasihat hukum;

Copyright (C) 2016, LITIGASI, p-ISSN: 0853-7100; e-ISSN: 2442-2274 
Available online at: http://ejournal.unpas.ac.id/index.php/litigasi

Litigasi, Vol. 17(2), 2016, 3517-3552

DOI: http://dx.doi.org/10.23969/litigasi.v17i2.156

o. Memperoleh bantuan biaya hidup sementara sampai batas waktu perlindungan berakhir; dan/atau

p. Mendapat pendampingan.

Demikian pula bagaimana mengajukan untuk mendapatkan hak bantuan medis; dan bantuan rehabilitasi psiko-sosial sebagaimana disebutkan di dalam Pasal 6 serta hak atas kompensasi bagi korban pelanggaran hak asasi manusia yang berat maupun hak atas restitusi atau ganti kerugian yang menjadi tanggung jawab pelaku tindak pidana, yang disebutkan di dalam Pasal 7 UU Perlindungan Saksi dan Korban.

Dalam praktik bentuk perlindungan yang menjadi tanggungjawab dan dilaksanakan LPSK dapat diklasifikasikan sebagai berikut: Perlindungan fisik, yaitu dilaksanakan dengan melakukan pemberian tindakan pengamanan, pengawalan, pendampingan setiap dilakukannya pemeriksaan, penempatan di rumah aman, pemeriksaan melalui tele/video conference (Pasal 9 ayat (1) UU No. 3 Tahun 2016). Dalam perspektif perlindungan saksi dan/atau korban pemeriksaan secara tele/video conference ini harus dipandang sebagai hak yang harus dihormati. Dalam praktik perlindungan oleh LPSK misalnya dilakukan terhadap saksi dalam kasus Cebongan Tahun 2013, namun patut disayangkan Majelis Hakim yang memeriksa pada waktu itu tidak mengijinkan pemeriksaan saksi secara tele/video conference), maupun penggantian identitas baru (penggantian identitas baru adalah mengganti identitas saksi dengan identitas yang baru atau berbeda dari identitas lamanya). Penggantian identitas ini

Copyright @ C 2016, LITIGASI, p-ISSN: 0853-7100; e-ISSN: 2442-2274 
Available online at: http://ejournal.unpas.ac.id/index.php/litigasi

Litigasi, Vol. 17(2), 2016, 3517-3552

DOI: http://dx.doi.org/10.23969/litigasi.v17i2.156

merupakan tindakan perlindungan dalam hal saksi berada pada situasi dan kondisi yang sangat berbahaya apabila masih dalam identitas lamanya.

Perlindungan hak prosedural, yaitu perlindungan yang berkaitan dengan administrasi peradilan pada setiap tahapan proses hukum yang dijalankan, misalnya hak untuk memberikan keterangan tanpa tekanan dalam setiap tahapan proses hukum yang berlangsung; hak untuk didampingi penerjemah; dalam hal keterbatasan atau terdapat hambatan berbahasa; hak untuk terbebas dari pertanyaan yang menjerat; hak untuk mendapatkan informasi mengenai perkembangan kasus hingga batas waktu perlindungan berakhir; hak untuk diberitahukan dalam hal terpidana dibebaskan; hak untuk didampingi oleh penasihat hukum dan mendapatkan nasihat-nasihat hukum; dan hak untuk mendapat dukungan pembiayaan seperti biaya transportasi dan biaya hidup sementara; dilaksanakan oleh LPSK baik dengan melakukannya sendiri maupun berkoordinasi dengan penegak hukum terkait untuk memastikan pemenuhannya, hal ini karena pemenuhan hak-hak dimaksud tidak bergantung pada LPSK semata, melainkan bergantung pula kepada penegak hukum seperti jaksa penuntut umum dan hakim. Misalnya dalam hal pelaksanaan hak bagi saksi untuk memberikan keterangan tanpa tekanan atau hak untuk terbebas dari pertanyaan yang menjerat; untuk hak dimaksud di persidangan seorang Jaksa Penuntut Umum dapat melakukan interupsi kepada Majelis Hakim untuk mengingatkan terhadap pertanyaan-pertanyaan menjerat atau menekan yang ditujukan kepada saksi. Oleh karena itu dalam menjaga pemenuhan hak

Copyright @ C 2016, LITIGASI, p-ISSN: 0853-7100; e-ISSN: 2442-2274 
Available online at: http://ejournal.unpas.ac.id/index.php/litigasi

Litigasi, Vol. 17(2), 2016, 3517-3552

DOI: http://dx.doi.org/10.23969/litigasi.v17i2.156

dimaksud LPSK akan intensif berkoordinasi dengan penegak hukum terkait.

1. Bantuan/layanan pemulihan, yaitu hak yang diberikan kepada korban atas akibat kerusakan atau penderitaan secara fisik dan/atau psikhis, dilaksanakan oleh LPSK dengan memberikan layanan medis, psikologis dan/atau layanan rehabilitasi psikososial.

2. Pemberian kompensasi atau restitusi, yaitu dilakukan oleh LPSK dengan memfasilitasi pengajuannya sesuai prosedur yang diatur dalam undangundang.

3. Pemberian penghargaan atau reward dapat diberikan kepada pelapor (whistleblower) dan/atau sebagai saksi pelaku yang berkerjasama (justice collaborator), sesuai dengan prosedur yang diatur dalam undang-undang.

B. LPSK Merupakan Lembaga Negara dalam Konteks Sistem Peradilan Pidana di Indonesia

Model lembaga perlindungan saksi dan korban dalam UU Perlindungan saksi dan korban adalah lembaga yang mandiri dan bertanggungjawab kepada presiden. Lembaga ini dibentuk sekurang-kurangnya dibentuk di ibukota provinsi dan diwilayah kabupaten/kota yang dianggap perlu oleh lembaga perlindungan saksi dan korban. Keanggotaan LPSK adalah 7 orang yang terdiri dari KOMNAS HAM, kepolisian, kejaksaan, Departemen kehakiman dan HAM, akademisi dan Lembaga Swadaya Masyarakat. UU ini tidak mengatur mengenai dukungan staf yang akan membantu kerja-kerja lembaga ini, misalnya staf yang

Copyright @ C 2016, LITIGASI, p-ISSN: 0853-7100; e-ISSN: 2442-2274 
Available online at: http://ejournal.unpas.ac.id/index.php/litigasi

Litigasi, Vol. 17(2), 2016, 3517-3552

DOI: http://dx.doi.org/10.23969/litigasi.v17i2.156

mempunyai kualifikasi untuk membuat rekomendasi berkaitan dengan tindakantindakan perlindungan saksi dan korban dan staf yang mempunyai kemampuan untuk mengatasi trauma tertentu yang dialami saksi dan korban.

Dalam Pasal 12 dinyatakan bahwa LPSK bertanggungjawab menangani pemberian perlindungan dan bantuan pada saksi dan korban berdasarkan ketentuan sebagaimana yang diatur dalam undang-undang ini. Walaupun dalam Pasal 16 LPSK bertanggung-jawab kepada presiden, namun dalam UU ini tidak dicantumkan secara jelas mengenai kewenangan, tugas dan kewajibannya secara rinci. Tidak diaturnya beberapa kewenangan dan tugas LPSK ini akan melemahkan tugas-tugas LPSK juga tidak jelas pada posisi mana dalam hubungannya dengan aparat penegak hukum lainnya.

Ranah fungsi LPSK berada dalam ranah kekuasaan executif. Hal ini sesuai dengan UU No. 13 Tahun 2006 jo UU No. 31 Tahun 2014 yang menyebutkan LPSK sebagai lembaga mandiri yang bertanggung jawab kepada Presiden, dalam konteks lembaga negara, LPSK sebagai LNS yang berada pada ranah executif yaitu memberikan dukungan terhadap sistem peradilan pidana yang baik, seimbang dan adil, yakni berupa perlindungan dan bantuan rehabilitasi terhadap saksi dan/atau korban tindak pidana. Secara keseluruhan kekuasaan negara dalam lingkup sistem peradilan pidana terdiri dari lembaga executif yang dilaksanakan oleh Kepolisian, Kejaksaan, Lembaga Pemasyarakatan (ditjen pemasyarakatan) dan LPSK, serta lembaga yudikatif, yakni Pengadilan Negeri, Pengadilan Tinggi maupun Mahkamah Agung. Dengan demikian, dalam 
Available online at: http://ejournal.unpas.ac.id/index.php/litigasi

Litigasi, Vol. 17(2), 2016, 3517-3552

DOI: http://dx.doi.org/10.23969/litigasi.v17i2.156

konteks perlindungan sebagai fungsi yang dilaksanakan LPSK dimaksud, maka LPSK akan bersentuhan dengan fungsi-fungsi lainnya, baik fungsi dari lembaga executif maupun fungsi dari lembaga yudikatif.

LPSK merupakan lembaga yang menjalankan salah satu fungsi penting yang diperlukan setiap tahap peradilan pidana. Keterlibatan fungsi perlindungan yang dilaksanakan LPSK dalam sistem peradilan pidana dapat digambarkan dalam gambar sebagai berikut:

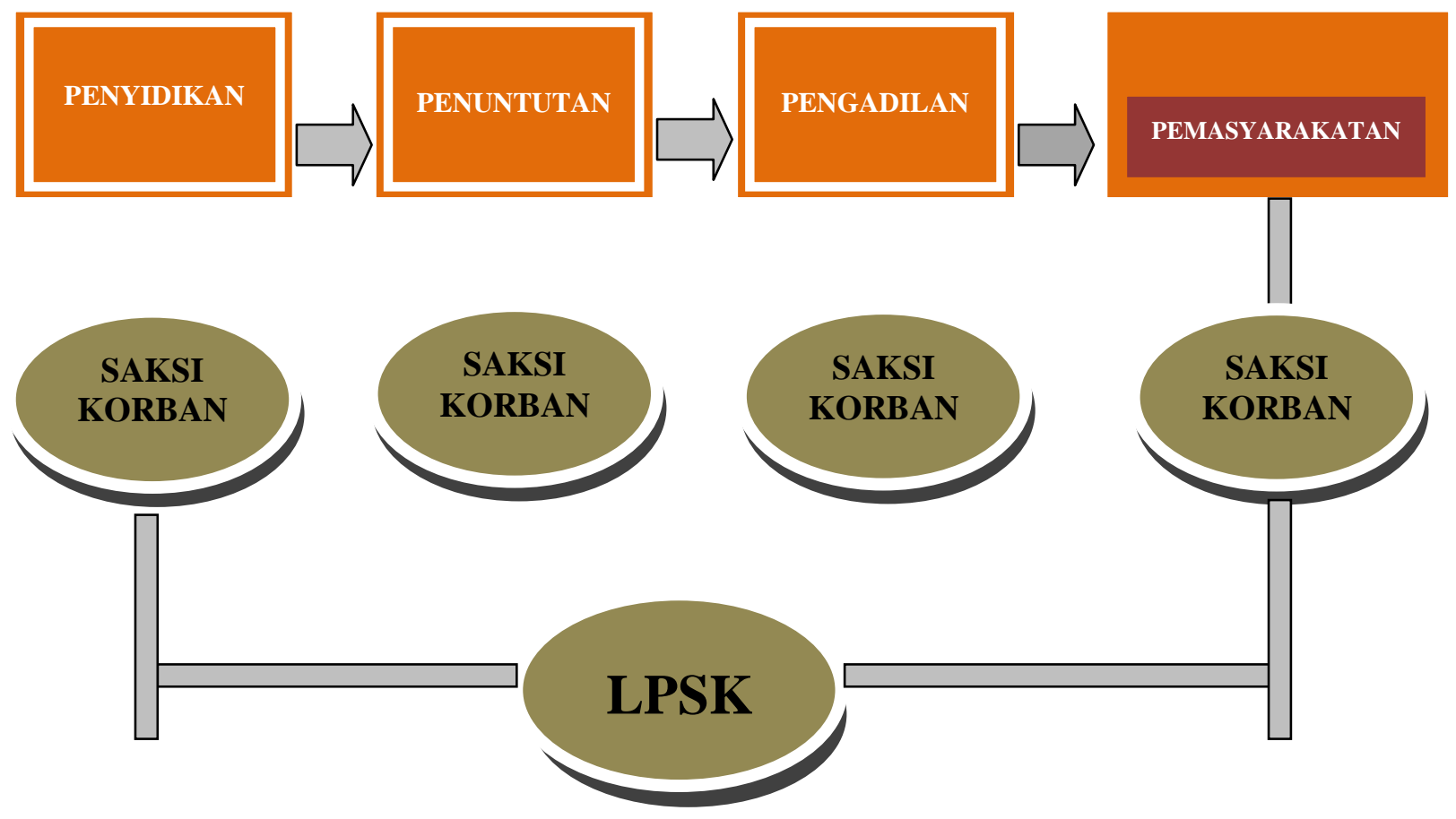

Bahwa berdasarkan ragaan di atas, dapat dijelaskan bahwa pada dasarnya fungsi perlindungan yang menjadi tanggung jawab LPSK adalah dalam rangka membangun sistem peradilan pidana yang sempurna, yakni melaksanakan pemberian perlindungan saksi dan korban tindak pidana yang dapat diberikan

Copyright $\odot$ 2016, LITIGASI, p-ISSN: 0853-7100; e-ISSN: 2442-2274 
Available online at: http://ejournal.unpas.ac.id/index.php/litigasi

Litigasi, Vol. 17(2), 2016, 3517-3552

DOI: http://dx.doi.org/10.23969/litigasi.v17i2.156

sejak tahap penyelidikan dimulai dan berakhir sesuai dengan ketentuan sebagaimana diatur dalam Undang-Undang (Pasal 2 dan Pasal 8 UU No. 13 Tahun 2006 jo. UU No. 31 Tahun 2014 Tentang Perubahan Atas UU No. 13 Tahun 2006).

Mengkaji fungsi yang dilaksanakan LPSK, maka fungsi dimaksud tidak merupakan duplikasi fungsi utama dari fungsi lembaga/institusi atau komponen lainnya dari sistem peradilan pidana. Kehadiran LPSK dalam ranah sistem peradilan pidana, justru penting untuk mendorong kelancaran pengungkapan bukti sehingga membuat terang suatu peristiwa tindak pidana, khususnya alat bukti keterangan saksi. Hal ini sekaligus juga akan mendorong dan mendukung terwujudnya sistem peradilan pidana yang baik, seimbang dan adil, yakni sebagai sistem peradilan pidana yang sempurna karena telah mengakomodasi hak- hak dan kepentingan para pihak yang terlibat dalam proses peradilan pidana, sehingga terdapat keseimbangan hak dan kepentingan antara pelaku, saksi maupun korban tindak pidana.

Copyright @ C 2016, LITIGASI, p-ISSN: 0853-7100; e-ISSN: 2442-2274 
Available online at: http://ejournal.unpas.ac.id/index.php/litigasi

Litigasi, Vol. 17(2), 2016, 3517-3552

DOI: http://dx.doi.org/10.23969/litigasi.v17i2.156

\section{SIMPULAN DAN SARAN}

\section{A. Simpulan}

1. Sampai saat ini acuan utama legislasi di Indonesia yang mengatur mengenai saksi termasuk hak dan perlindungannya ada dalam Kitab Undang-undang Hukum Acara Pidana (KUHAP) dan peraturan lain di bawahnya. Aturan dalam KUHAP inilah yang merupakan payung dari seluruh hukum acara pidana di Indonesia yang pertama mengatur mengenai saksi dan hakhaknya. Pengertian atau misi saksi dapat dilihat dalam Pasal 1 angka 36 Kitab Undang-undang Hukum Acara Pidana. Menurut KUHAP, saksi adalah orang yang dapat memberikan keterangan guna kepentingan penyidikan, penuntutan dan peradilan tentang suatu perkara pidana yang ia dengar sendiri, ia lihat sendiri, dan ia alami sendiri. Pengaturan dan prosedurnya diatur yakni yang diatur dalam Undang-Undang No. 26 tahun 2000 tentang Pengadilan HAM; Undang-Undang No. 25 Tahun 2003 tentang perubahan UU No. 15 Tahun 2002 tentang tindak pidana pencucian uang; dalam UU Nomor 30 Tahun 2002 yang secara khusus mengatur mengenai komisi pemberantasan korupsi. Salah satu kewajiban dari KPK dalam UU ini adalah memberikan perlindungan terhadap saksi atau pelapor yang menyampaikan laporan atau memberikan keterangan mengenai terjadinya tindak pidana korupsi; Undang-Undang No. 26 Tahun 2000 tentang Pengadilan Hak Asasi Manusia; Undang-Undang No. 23 Tahun 2002 tentang Perlindungan Anak, Undang-Undang No. 15 Tahun 
Available online at: http://ejournal.unpas.ac.id/index.php/litigasi

Litigasi, Vol. 17(2), 2016, 3517-3552

DOI: http://dx.doi.org/10.23969/litigasi.v17i2.156

2003 tentang Tindak Pidana Terorisme; Undang-Undang No. 23 Tahun 2004 tentang Penghapusan Kekerasan dalam Rumah Tangga. Dalam sebuah proses peradilan pidana, aparat keamanan LPSK memiliki peran sangat penting dalam mencapai tujuan sistem peradilan pidana yang baik, seimbang dan adil, yakni sebagai sebuah sistem yang memenuhi perasaan keadilan masyarakat, baik keadilan prosedural maupun keadilan substansial. Peran LPSK tersebut adalah dengan melaksanakan fungsi perlindungan terhadap saksi dan/atau korban tindak pidana, sehingga proses penyidikan, penuntutan maupun pemeriksaan di persidangan, antara lain tidak mengalami kesulitan atau hambatan dalam melakukan pemeriksaan terhadap saksi dan/atau korban guna mendapatkan alat bukti, karena saksi dan/atau korban dimaksud telah mendapatkan jaminan perlindungan yang diperlukan.

2. LPSK merupakan lembaga negara yang masuk dalam kategori state youx diary organ yang dalam praktik sering disebut juga LNS (lembaga non struktural). Kedudukan LPSK dalam sistem peradilan pidana di Indonesia adalah sebagai komponen sistem peradilan pidana yang memiliki fungsi penting dalam penegakan hukum, khususnya memberikan perlindungan terhadap saksi maupun korban, dalam rangka mendapatkan kebenaran materiel serta mewujudkan sistem peradilan pidana yang baik, seimbang dan adil.

Copyright @ C 2016, LITIGASI, p-ISSN: 0853-7100; e-ISSN: 2442-2274 
Available online at: http://ejournal.unpas.ac.id/index.php/litigasi

Litigasi, Vol. 17(2), 2016, 3517-3552

DOI: http://dx.doi.org/10.23969/litigasi.v17i2.156

\section{B. Saran}

Lembaga Perlindungan Saksi dan Korban (LPSK) sebagai komponen sistem peradilan pidana perlu secara tegas diakui dalam hukum acara pidana sehingga guna mengakomodir ini perlu segera dilakukan revisi terhadap Kitab UndangUndang Hukum Acara Pidana.

Copyright @ 2016, LITIGASI, p-ISSN: 0853-7100; e-ISSN: 2442-2274 


\section{DAFTAR PUSTAKA}

\section{BUKU}

Achmad Ali, 2001, Keterpurukan Hukum Di Indonesia, (Penyebab dan Solusinya), Jakarta, Ghalia Indonesia.

Arif Gosita, 1986, Viktimologi dan KUHAP, Jakarta, Akademika Presindo.

Dikdik M. Arief Mansur dan Elisatris Gultom, 2007, Urgensi Perlindungan Korban Kejahatan, Jakarta, Rajagrafindo Persada.

Hamdan Zoelva, 2010, Tujuan Konstitusional Penataan Lembaga Non Struktural, dalam: Bunga Rampai Pemikiran Penataan Lembaga Non Struktural, Jakarta, Kementrian Sekretaris Negara.

Hanafi Asmawie, 1989, Ganti Rugi dan Rehabilitasi menurut KUHAP, Jakarta, Pradnya Paramita.

Jimly Asshiddiqie, 2006, Pengantar IImu Hukum Tata Negara, Jilid I, Jakarta, Konstitusi Press.

Mien Rukmini, 2006, Aspek Hukum Pidana Dan Kriminologi (sebuah bunga rampai), Bandung, Alumni.

2003, Perlindungan HAM Melalui Asas Praduga Tidak Bersalah dan Asas Persamaan Kedudukan Dalam Hukum Pada Sistem Peradilan Pidana Indonesia, Bandung, PT. Alumni.

M. Yahya Harahap, 1988, Pembaharuan dan Penerapan KUHAP, Jakarta, Metropolitan Press.

Muladi dan Barda Nawawi Arief, 2007, Bunga Rampai Hukum Pidana, Bandung, Alumni.

Soeharto, 2007, Perlindungan Hak Tersangka Terdakwa, dan Korban Tindak Pidana Terorisme Dalam Sistem Peradilan Pidana Indonesia, Bandung, Refika Aditama.

Satjipto Rahardjo, 2009, Penegakan Hukum Suatu Tinjauan Sosiologis, Yogyakarta, Genta Publishing. 
Taufiq Effendi, 2010, Efektivitas Kelembagaaan Dan Strategi Penataan Lembaga Non Struktural', Bunga Rampai Pemikiran Penataan Lembaga Non Struktural, Jakarta, Kementrian Sekretaris Negara.

JURNAL

Artidjo Alkostar, Restorative Justice, Varia Peradilan Nomor 262, September 2007.

\section{MAKALAH}

Juanda, 2003, Paradigma Dalam Memerangi Tindak Pidana Korupsi Di Indonesia, Makalah, Bengkulu.

\section{PERATURAN PERUNDANGAN}

Undang-Undang No. 8 Tahun 1981 tentang Kitab Undang-Undang Hukum Acara Pidana.

Undang-Undang No. 26 Tahun 2000 tentang Pengadilan Hak Asasi Manusia.

Undang-Undang No. 23 Tahun 2002 tentang Perlindungan Anak.

Undang-Undang No. 30 Tahun 2002 tentang Komisi Pemberantasan Korupsi.

Undang-Undang No. 15 Tahun 2003 tentang Tindak Pidana Terorisme.

Undang-Undang No. 25 Tahun 2003 tentang perubahan UU No. 15 Tahun 2002 tentang Tindak Pidana Pencucian Uang.

Undang-Undang No. 23 Tahun 2004 tentang Penghapusan Kekerasan dalam Rumah Tangga.

Undang-Undang No. 31 Tahun 2014 Tentang Perubahan Atas Undang-Undang No. 13 Tahun 2006 Tentang Perlindungan Saksi dan Korban. 